\title{
Direitos Humanos e Desenvolvimento Sustentável na Busca de uma Justiça Fraterna Social: Reflexões em Direção à Rio +20
}

\section{DAVIDSON ALESSANDRO DE MIRANDA}

Advogado, Professor, Mestrando da Escola Superior Dom Helder Câmara (ESDHC) (Belo Horizonte/MG).

\section{ANDREIA AMORIM NEDER}

Mestranda em Direito Ambiental e Desenvolvimento Sustentável pela Escola Superior Dom Helder Câmara (ESDHC), Graduada em Comunicação Social (com ênfase em Relações Públicas pela Faculdade Newton Paiva), Graduanda em Direito pela PUC-Minas.

Submissão: 06.05.2012

Decisão Editorial: 28.06.2012

RESUMO: No Pós II Guerra Mundial, o homem passou a se considerar titular de uma dignidade a ser protegida na ordem jurídica nacional e principalmente internacional. A Organização Internacional das Nações Unidas - ONU inseriu os direitos humanos nas discussões socioeconômicas culturais. As Conferências Mundiais consolidaram a inserção do direito ao desenvolvimento no âmbito conceitual dos direitos humanos, principalmente quanto à sustentabilidade, na busca de medidas e programas de promoção do desenvolvimento, com o propósito de evitar a escassez dos recursos naturais, tão necessários à existência da humanidade. Neste cenário surge a terceira dimensão de direitos, chamada direitos da fraternidade, referentes ao direito à paz, à proteção ao meio ambiente ecologicamente sustentável, à qualidade de vida, ao desenvolvimento, à manutenção do patrimônio comum da humanidade, à autodeterminação dos povos, direitos esses de implicação universal. Na história da humanidade, verifica-se que os direitos não foram recriados, mas insurgidos diante de tanta desigualdade e diferenças, o que se constata nos diversos documentos e pactos históricos, com o fim único de se manter a configuração e a busca de um direito fraterno e comum para todos. A intenção desse estudo é verificar que o documento "Our Common Future", conhecido também como Relatório Brundtland, é bem atual, pois trata do crescimento populacional, o qual ocasiona desequilíbrio na cadeia alimentar, no meio ambiente e nos recursos energéticos, evidenciando a necessidade de, 0 quanto antes, elaborar estratégias de políticas públicas que tenham objetivos demográficos gerais e específicos que visem a fortalecer o desenvolvimento sustentável pautado na justiça fraterna social.

PALAVRAS-CHAVE: Direitos humanos; direitos fundamentais; desenvolvimento sustentável; justiça; direito fraterno; solidariedade; meio ambiente; humanidade; políticas públicas; sustentabilidade; conferências; população; devastação; desequilíbrio; recursos energéticos. 
ABSTRACT: Post World War II, the man began to consider holding a dignity to be protected in the National Legal Order and especially internationally. The International Organization of the United Nations - UN Human Rights entered into discussions socioeconomic culture. The World Conference consolidated the insertion of the right to develop the conceptual framework of human rights, especially regarding sustainability in the pursuit of measures and programs to promote the development, in order to avoid shortages of natural resources, as necessary the existence of mankind. In this scenario comes the Third Dimension Rights, called rights of brotherhood, for the right to peace, environmental protection environmentally sustainable, quality of life, development, maintenance of the common heritage of mankind, self-determination, rights of involvementuniversal. In human history, it appears that the rights have not been rebuilt, but insurgidos face of such inequality and differences, which can be seen in many historical documents and agreements for the sole purpose of maintaining the setting and pursuit of a law fraternity and common to all. The intent of this study is to verify that the document "Our Common Future" also known as the Brundtland Report, it is very current, as this population growth, which causes imbalance in the food chain, environment, energy resources, highlighting the need for much prior to devise strategies for public policies that have general and specific demographic goals aimed at strengthening the sustainable development guided by the fraternal social justice.

KEYWORDS: Human rights; fundamental rights; sustainable development; justice; fraternal law; solidarity; environment; humanity; public policy; sustainability conference; population; devastation; imbalance; energy resources.

SUMÁRIO: Introdução; 1 Direito humano ao desenvolvimento sustentável; 1.1 Origens da proteção jurídica ao desenvolvimento sustentável; 1.2 Direito ao desenvolvimento; 1.2.1 Conceito; 1.2.2 Titularidade; 1.2.3 Dimensões; 1.3 Direito do desenvolvimento; 1.4 Desenvolvimento sustentável; 2 A criação e importação do direito fraterno no contexto mundial; 2.1 Direitos fundamentais e direitos humanos; 2.2 Solidariedade social no Direito brasileiro; 3 Políticas públicas de sustentabilidade; 3.1 Políticas públicas - Análise conceitual; 3.2 Sustentabilidade; 3.2.1 Conceito; 3.2.2 Origem; 3.2.3 Dimensões do termo de sustentabilidade; 3.2.4 Implementação de políticas públicas de sustentabilidade no Brasil; 4 Documento "Our Commnon Future" e o desenvolvimento sustentável definido em plano internacional; 4.1 Análise do teor "Our Common Future"; 4.1.1 Origem das discussões; 5 Desenvolvimento economicamente viável e socialmente justo; 5.10 binômio crescimento da população e produção alimentícia; 5.2 Devastação ambiental e a realidade energética; 5.3 Os efeitos da produção industrial; 6 A efetivação dos direitos humanos fundamentais no judiciário brasileiro e a análise da cláusula de reserva do possível; Considerações finais; Referências.

\section{INTRODUÇÃO}

O presente artigo tende a discorrer sobre direitos humanos e desenvolvimento sustentável na busca de uma justiça fraterna social, que possa suscitar reflexões em direção à Rio +20 .

Para tanto, abordou-se a origem, os conceitos e as evoluções dos direitos fundamentais/humanos em amplitude universal como forma de efetivar o desenvolvimento sustentável tanto no cenário nacional como no internacional.

O marco desse processo se deu com a II Guerra Mundial, e, a partir de então, o homem passou a se considerar titular de uma dignidade a ser protegi- 
da na ordem jurídica nacional e principalmente internacional. A Carta de São Francisco motivou a criação da Organização Internacional das Nações Unidas - ONU, inserindo os direitos humanos nas discussões políticas, jurídicas, sociais, econômicas e culturais, na defesa da paz e existência da humanidade.

A abordagem norteia-se pela Declaração de 1986, pela Declaração de Viena de 1993 e pela Conferência de Caio em 1994, esta última reafirmando o direito ao desenvolvimento como direito humano inalienável, o qual também é defendido na Cúpula de Copenhage para o Desenvolvimento Social em 1995.

Nessa feita, pela Declaração de 1986 e pelas Conferências Mundiais posteriores consolidou-se a inserção do direito ao desenvolvimento no âmbito conceitual dos direitos humanos, principalmente quanto à sustentabilidade, com o propósito de identificar medidas e programas para a promoção do desenvolvimento, traçada de forma a evitar a escassez dos recursos naturais, tão necessários à existência da humanidade.

Diante dessa realidade, aponta-se o conceito do direito do desenvolvimento, bem como o direito ao desenvolvimento, sendo que o primeiro é definido como normas que tratam de políticas econômicas que visam a alterar a ordem jurídica no contexto nacional e internacional; enquanto que o segundo aborda os direitos humanos no âmbito do direito internacional, garantindo o acesso natural dos homens a esse direito, independentemente da sua nacionalidade, cidadania ou outras particularidades, por ser um direito ao mesmo tempo individual e coletivo, baseado na cooperação internacional. Nesse cenário destaca-se a presença de dimensões, tendo-se entre elas: a de caráter fundamental, dever internacional de solidariedade, interdependência moral, interdependência econômica, a manutenção da paz e da segurança mundial e, por fim, o dever moral de reparação.

Dessarte, que o desenvolvimento das nações se apoia e deve observância aos novos paradigmas e aos novos valores no domínio da economia concebida como de livre mercado, integrando-se com as dimensões social, ambiental e institucional, ao que é chamado desenvolvimento sustentável para a qualidade de vida das presentes e futuras gerações, pois cada ser humano, assim como toda a humanidade, deve ter acesso às condições de desenvolvimento, como também de um ambiente ecologicamente equilibrado e saudável.

Desta forma, com o pós II Guerra começa a desenvolver a terceira dimensão de direitos, chamados direitos da fraternidade, referentes ao direito à paz, à proteção ao meio ambiente ecologicamente sustentável, à qualidade de vida, ao desenvolvimento, à manutenção do patrimônio comum da humanidade, à autodeterminação dos povos, direitos esses de implicação universal.

Verifica-se que na história da humanidade os direitos não foram recriados, mas insurgidos diante de tanta desigualdade e diferenças, as quais impostas àqueles que dependem de tais direitos. Fato que pode ser constatado nos diver- 
sos documentos e pactos históricos com o fim único de se manter a configuração e a busca de um direito fraterno e comum para todos, como se verifica no Plano de Ação para Prevenção e Controle do Desmatamento da Amazônia Legal, Pacto Internacional sobre Direitos Econômicos, Sociais e Culturais e o documento "Our Common Future", conhecido também como Relatório Brundtland, da Organização das Nações Unidas da Comissão Mundial sobre Meio Ambiente e Desenvolvimento (WCED).

Por meio do Relatório Brundtland, defende-se a interdependência das nações, mediante o crescente desenvolvimento tecnológico e industrial, bem como a necessidade de compatibilizar tal crescimento com a busca de um desenvolvimento sustentável. No ano em que esse relatório foi entregue, o crescimento populacional não era visto como a principal ameaça para a harmonia do planeta, situação que destoa da realidade mundial atual, tendo em vista que hoje vinculadas ao desenvolvimento estão as questões sobre o aquecimento global, envenenamento do solo e da água por meio de produtos químicos, vazamento de petróleos, entre outras formas antrópicas poluidoras.

O que se observa é que as questões abordadas no Relatório Brundtland são bem atuais, como se observa nos posicionamentos recentes expressos nas decisões do Judiciário brasileiro.

A questão do crescimento populacional, se faz presente nos dias de hoje assim como na época do Relatório de Brundtland, na medida em que o desequilíbrio na cadeia alimentar, no meio ambiente e nos recursos energéticos exige o quanto antes a elaboração e a aplicação de políticas públicas que tenham objetivos demográficos gerais e específicos que visem a fortalecer as motivações sociais, culturais e econômicas em torno do desenvolvimento sustentável pautado na justiça fraterna social.

\section{DIREITO HUMANO AO DESENVOLVIMENTO SUSTENTÁVEL}

\subsection{Origens da PRoteç̃̃o JuRídica AO deSENVOLVIMENTO SUStentável}

Após as atrocidades da II Guerra Mundial, o ser humano passou à consideração de titular de uma dignidade a ser protegida na ordem jurídica nacional e principalmente internacional. Seguindo as lições de lanni,

o desenvolvimento pode ser analisado sob um caráter multidisciplinar, o qual tem o homem como objeto central e deve fundamentar tratados gerais e especiais, bem como resoluções que tratem de interesses dos Estados e das Organizações Intergovernamentais, tais como a Carta de São Francisco, que criou a Organização Internacional das Nações Unidas - ONU e que estabeleceu as bases do Direito Internacional como direito de estruturação da sociedade global. ${ }^{1}$ 
$\mathrm{O}$ art. $1^{\circ}$ da Carta de São Francisco reconheceu o caráter universal do homem e dos seus direitos. Já a Declaração Universal dos Direitos do Homem, por intermédio de seu preâmbulo, reafirmou vários princípios contidos na Carta de São Francisco, além de conteúdos que seriam objeto da definição do direito ao desenvolvimento. Neste contexto, vale ressaltar que o mencionado art. 22 da Carta de São Francisco dispôs que toda pessoa, como membro da sociedade, tem direito à segurança social e à realização - pelo esforço nacional, pela cooperação internacional de acordo com a organização e recursos de cada Estado - dos direitos econômicos, sociais e culturais indispensáveis à sua dignidade e ao livre desenvolvimento da sua personalidade.

Conforme Trindade², os Pactos Internacionais de 1966, somados à Declaração Universal de 1948, foram os responsáveis pela formação da Carta Internacional dos Direitos Humanos, alcançando anseios antigos acerca de um plano geral consubstanciado em uma Carta Internacional de Direitos Humanos, da qual a Declaração seria apenas a primeira parte a ser complementada por uma Convenção ou Convenções - posteriormente denominadas Pactos.

Também seguindo o lecionado pelo autor supra, tem-se que a Declaração Universal, de dezembro de 1948, foi precedida em meses pela Declaração Americana dos Direitos e Deveres do Homem (de abril de 1948).

A Carta de Bogotá de 1948 adotou o homem como fundamento da sua ordem, definindo, em seu Capítulo VII, o desenvolvimento integral, conforme preceitos do art. 29, sendo que a Conferência de São José da Costa Rica, em 1969, negociou e aprovou a Convenção Americana sobre Direitos Humanos, que, em seu art. 26, dispõe acerca do desenvolvimento progressivo.

Após uma análise do conteúdo dos tratados de direitos humanos retrocitados, observa-se a amplitude destes direitos firmados por intermédio das Nações Unidas, bem como por organismos regionais, v.g., OEA, adquirindo-se condições para o oferecimento das bases estruturais do direito internacional dos direitos humanos, campo autônomo do direito internacional público, tornando-se possível, também, a perfeita distinção entre os conteúdos do direito do desenvolvimento e do direito ao desenvolvimento.

Segundo Accioly ${ }^{3}$, tendo em vista o crescente aumento da tecnologia, a aceleração repentina e extremamente rápida da produção industrial e o aprimoramento tecnológico assustador, levou ao processo também rápido de degradação ambiental, surgindo a necessidade de estudos comuns acerca do meio ambiente e do desenvolvimento.

2 TRINDADE, Antônio Augusto Cançado. O legado da declaração universal e o futuro da proteção internacional dos direitos humanos. In: AMARAL JÚNIOR, Alberto do; MOISÉS, Cláudia Perrone (Org.). O cinquentenário da declaração universal dos direitos do homem. São Paulo: Edusp, 1999. p. 17.

3 ACCIOLY, Hildebrando. Manual de direito internacional público. 12. ed. São Paulo: Saraiva, 1996. p. 391. 
A mencionada inter-relação ficou demonstrada na Conferência de Estocolmo sobre Meio Ambiente, cuja convocação coube ao Conselho Econômico e Social (ECOSOC), em 1972, sendo considerado o marco inicial do movimento ecológico.

Entretanto, mesmo após 10 (dez) anos da histórica Conferência de Estocolmo de 1972, a destruição do meio ambiente, associada ao uso irracional dos recursos não renováveis da natureza, assustava cada vez mais as organizações ambientais, levando a Assembleia-Geral das Nações Unidas a convocar uma nova Conferência.

Entretanto, previamente à mencionada Conferência, seriam tomadas diversas medidas de preparação, entre elas a formação de uma Comissão Mundial sobre Meio Ambiente e Desenvolvimento, em 1983, presidida pela ministra, Gro Harlen Brundtland, da Noruega.

Tal Comissão fez uma peregrinação por todos os países, consultando diversos líderes e outros formadores de opinião; foram realizadas várias reuniões deliberativas em inúmeras cidades, sendo que o término dos trabalhos aconteceu em 31 de dezembro de 1987, com o Relatório Brundtland - "Our Common Future - Nosso Futuro Comum", determinando o conceito de desenvolvimento sustentável tal qual definido na Declaração do Rio de Janeiro sobre o Meio Ambiente e Desenvolvimento.

Em 1992, no Rio de Janeiro, a sociedade internacional, por intermédio da maioria dos chefes de Estado e de Governo, realizou a Conferência Mundial sobre Meio Ambiente, demonstrando a necessidade de tratamento conjunto dos problemas do desenvolvimento socioeconômico e do meio ambiente e estabelecendo o conceito de desenvolvimento sustentável, no Princípio $3^{\circ} \mathrm{c} / \mathrm{c}$ o Princípio 4 ․

Tais princípios determinavam o seguinte:

Princípio $3^{\mathrm{o}} \mathrm{O}$ direito ao desenvolvimento deve ser exercido de modo a permitir que sejam atendidas equitativamente as necessidades de gerações presentes e futuras.

Princípio 4ํㅜㄹa alcançar o desenvolvimento sustentável, a proteção ambiental deve constituir parte integrante do processo de desenvolvimento, e não pode ser considerada isoladamente deste.

Deste momento em diante, ficou consagrada a visão de que o direito ao desenvolvimento dever ser visto, de modo indissolúvel, quanto ao aspecto da sustentabilidade.

Em 1993, a Conferência Mundial de Direitos Humanos de Viena reafirmou, em seu art. 10, o direito ao desenvolvimento, como inalienável e parte integrante dos direitos humanos fundamentais.

Em Cairo, no ano de 1994, ocorreu a Conferência Internacional sobre população e Desenvolvimento, que dedicou atenção especial ao direito ao desenvolvimento em seu Princípio $3^{\circ}$ : 
Princípio $3^{\circ} \mathrm{O}$ direito ao desenvolvimento é um direito universal e inalienável e parte integrante dos direitos humanos fundamentais, e a pessoa humana é o sujeito central do desenvolvimento. Se bem o desenvolvimento facilita o gozo de todos os direitos humanos, a falta de desenvolvimento não deve ser invocada para justificar a redução dos direitos humanos internacionalmente reconhecidos. $\mathrm{O}$ direito ao desenvolvimento deve ser realizado de modo a atender equitativamente as necessidades da população, do desenvolvimento e do meio-ambiente das gerações presentes e futuras.

A Conferência de Cairo reafirmou o direito ao desenvolvimento como um direito humano inalienável, já mencionado na Declaração de 1986 e na Declaração de Viena de 1993, sendo que, em 1995, ocorreu a Reunião de Cúpula de Copenhague para o Desenvolvimento Social, na qual se afirmou, mais uma vez, o conceito de desenvolvimento sustentável.

Sendo assim, por meio da Declaração de 1986 e do ciclo das Conferências Mundiais posteriores, houve a inserção e cristalização do direito ao desenvolvimento no âmbito conceitual dos direitos humanos, principalmente quanto ao aspecto da sustentabilidade, permitindo que medidas e programas capazes de auxiliar na promoção do desenvolvimento fossem traçados, de forma a se evitar o esgotamento dos recursos naturais.

\subsection{DiReito aO deSenVOLVIMENTO}

\subsubsection{Conceito}

O direito ao desenvolvimento pode ser conceituado como um direito do homem, dos Estados e dos povos, ao passo que o direito do desenvolvimento configura um direito exclusivo dos Estados.

Segundo Moisés ${ }^{4}$, o direito ao desenvolvimento está inserido no âmbito do direito internacional dos direitos humanos, sendo que a ele têm acesso natural todos os homens, independentemente da sua nacionalidade, cidadania, de serem povos indígenas ou miseráveis, quer seja em sociedades desenvolvidas ou em desenvolvimento.

Neste contexto, cabe aos homens os mesmos direitos ao conhecimento, ao mesmo tipo de valores sobre os elementos fundamentais da vida, portadores que são do referencial comum que os caracteriza como integrantes da humanidade.

Sob a ótica da ONU, o direito ao desenvolvimento é uma potencialidade, na medida em que possibilita aos seres humanos a opção pelo exercício de sua cidadania, conservando-se no equilíbrio (entre estagnação e crescimento), ado-

4 MOISÉS, Cláudia Perrone. Direito ao desenvolvimento e investimentos estrangeiros. São Paulo: Oliveira Mendes, 1998. p. 186. 
tando posturas que impliquem o desenvolvimento (sob os relevantes aspectos social, educacional, cultural, econômico, político, religioso e ambiental).

Ainda, consoante Moisés ${ }^{5}$, sob o aspecto do desenvolvimento progressivo de uma nova ordem mundial e reafirmando o conteúdo do art. $1^{\circ}$, $\S 3^{\circ}$, da Carta das Nações Unidas, a expressão "direito ao desenvolvimento", necessariamente implica uma atividade, devendo ser prevista a solidariedade/comunhão dos países desenvolvidos e daqueles em desenvolvimento, sob forma de consagração da justiça econômica distributiva.

\subsubsection{Titularidade}

Há 3 (três) correntes sobre a titularidade do direito ao desenvolvimento: uma o considera um direito individual; outra um direito coletivo; e a última o considera um direito individual e coletivo, simultaneamente.

A primeira corrente se baseia na tradição histórica ocidental, a qual concebe os direitos humanos como direitos individuais. Essa posição é minoritária, porque o direito ao desenvolvimento como direito individual passaria a ser uma síntese dos direitos existentes, acrescentando muito pouco.

O caráter coletivo do direito ao desenvolvimento foi defendido pelo bloco soviético e por grande parte dos países em desenvolvimento, bem como por muitos internacionalistas, sendo que, para tais autores, se apenas os aspectos individuais do direito ao desenvolvimento forem considerados, haverá uma pequena contribuição para a solução do problema do subdesenvolvimento, um problema que tem raízes de tipo coletivo e estrutural.

Já a postura que considera o direito ao desenvolvimento como individual e coletivo é defendida por alguns países, como França, Bélgica, Holanda e Brasil, optando por uma postura de equilíbrio entre o lado individual e o lado coletivo deste direito humano, mas o indivíduo ostenta uma posição privilegiada e é sujeito central do desenvolvimento, tal qual preleciona o art. $2^{\circ}$ da Declaração Universal dos Direitos Humanos.

Para Bobbio ${ }^{6}$, o direito ao desenvolvimento é um direito humano e da humanidade, sendo um direito individual no plano interno e coletivo no plano internacional.

Neste contexto, há de se ressaltar que - a nosso entender - a terceira corrente configura a mais sensata e a mais coerente, partindo-se do princípio de que a humanidade é formada pela união de seres individuais, e, ao se agredir o direito de um indivíduo, agride-se o direito de toda a humanidade; sendo assim,

5 MOISÉS, Cláudia Perrone. Direitos humanos e desenvolvimento: a contribuição das nações unidas. In: AMARAL JÚNIOR, Alberto do; MOISÉS, Cláudia Perrone (Org.). O cinquentenário da declaração universal dos direitos do homem. São Paulo: Edusp, 1999. p. 50. 
há de se considerar o direito ao desenvolvimento em seu aspecto individual e coletivo.

\subsubsection{Dimensões}

$\mathrm{Isa}^{7}$ encontra diversos fundamentos para embasar a existência do direito ao desenvolvimento em princípios filosóficos, éticos, morais e religiosos e destaca os argumentos oferecidos pelo Secretário Geral da ONU em informe consubstanciado no estabelecimento de dimensões internacionais do direito ao desenvolvimento como direito humano em relação aos outros direitos humanos baseados na cooperação internacional, entre os quais o direito à paz (E/CN. 4/1334, de 11 de dezembro de 1978).

Uma das dimensões internacionais do direito ao desenvolvimento configura o caráter fundamental deste consubstanciado no fato de que a promoção do desenvolvimento é uma preocupação fundamental de todos os esforços humanos.

Outra dimensão é a do dever internacional de solidariedade para o desenvolvimento, cuja origem está presente na própria Carta de São Francisco de 1945, tratando-se da afirmação do direito aos povos mais pobres em participarem das riquezas do mundo.

A interdependência moral é outra dimensão a ser estudada, impondo a todos os níveis uma responsabilidade crescente no que atine à aplicação de princípios morais nas relações entre os povos pela busca do desenvolvimento sustentável.

Nesse diapasão, a fome e o subdesenvolvimento de uma parcela muito importante da humanidade tornam-se os problemas morais mais graves da contemporaneidade, sendo que existem diversas respostas para solucioná-los ou abrandá-los por parte da comunidade científica e econômica mundial.

Há a interdependência econômica, significando que a promoção do direito ao desenvolvimento traz benefícios tanto para os países em desenvolvimento quanto para os países desenvolvidos, caracterizando a "solidariedade egoísta" ou do "egoísmo ilustrado", na medida em que a promoção do desenvolvimento do terceiro mundo é movida não por considerações de cunho ético, moral e humanitário, mas pela possibilidade de trazer benefícios aos países desenvolvidos.

Uma dimensão de suma importância é a manutenção da paz e da segurança mundial, já que as diferenças econômicas, sociais e culturais são demasiadamente grandes entre os povos do mundo e provocam tensões e discórdias, colocando a paz em perigo.

7 ISA, Felipe Gomez. Cuadernos Deusto de derechos humanos: Ios derechos humanos al desarrollo: entre la justicia y la solidaridad. Bilbao: Universidade Deusto, 1998. p. 23. 
O dever moral de reparação é a última dimensão internacional do direito ao desenvolvimento, afirmando que este direito decorre do dever moral de reparação que recai sobre os países desenvolvidos, em decorrência dos excessos cometidos por eles no seu passado colonial.

\subsection{DiReito ao desenVOLIIIENTO}

Segundo Moisés ${ }^{8}$, tal direito tem por desiderato o de estabelecer modelos de vida para uma sociedade, sendo formado por normas que tratam de políticas econômicas e visam à modificação estrutural da ordem jurídica, tanto no âmbito nacional quanto no internacional.

O direito internacional do desenvolvimento não é formado por um conjunto homogêneo de normas, pois estas formam um "quebra-cabeça", na medida em que os princípios e as normas de tal Direito estão estabelecidos em declarações e resoluções de organismos internacionais, diferentemente do direito internacional tradicional, cujas principais fontes continuam sendo o tratado e o costume, bem como o próprio direito internacional econômico, cuja fonte principal é o tratado internacional.

As principais declarações e resoluções que tratam do direito do desenvolvimento são as seguintes: a) Resolução $n^{0}$ 2.626, que trata da Estratégia Internacional do Desenvolvimento; b) Resoluções nos 3.201 e 3.202, que tratam da Declaração da Nova Ordem Econômica Internacional e do Programa de Ação, respectivamente; c) Resolução no 3.291, que trata da Carta dos Direitos e Deveres Econômicos dos Estados. Na opinião de citado por Celso Mello9 ${ }^{9}$, o direito internacional do desenvolvimento apresenta duas características.

Em primeiro lugar, o termo "desenvolvimento" é um conceito antigo, apesar de ter assumido significados diversos, quer sob a ótica puramente econômica, quer sob a ótica multidisciplinar, abarcando os aspectos econômicos, sociais e culturais.

E, em segundo lugar, o objetivo primordial do direito internacional do desenvolvimento é procurar soluções para as questões apresentadas pela diferença econômica entre os diversos Estados, lembrando que a nova ordem econômica não era concebida somente para o combate das desigualdades materiais, mas das desigualdades refletidas nas estruturas jurídicas e políticas como forma de auxiliar na reestruturação do direito internacional.

8 MOISÉS, Cláudia Perrone. Direitos humanos e desenvolvimento: a contribuição das nações unidas. In: AMARAL JÚNIOR, Alberto do; MOISÉS, Cláudia Perrone (Org.). Op. cit., p. 406/407.

9 MELLO, Celso D. de Albuquerque. Curso de direito internacional público. 11. ed. Rio de Janeiro: Renovar, v. 1 e 2,1997 . p. 1517. 


\subsection{Desenvolvimento SustentáveL}

Benjamim ${ }^{10}$ leciona que o termo Desenvolvimento Sustentável surgiu em 1980 e foi consagrado em 1987, no relatório Nosso Futuro Comum, na Comissão Mundial sobre Meio Ambiente.

Para esta Comissão, a exploração dos recursos, a direção dos investimentos, a orientação do desenvolvimento tecnológico e a mudança institucional se harmonizam e reforçam um potencial presente e futuro, a fim de atender às aspirações futuras, sem comprometer a possibilidade de as gerações futuras atenderem as suas próprias necessidades.

Em 1992, com a realização da Conferência das Nações Unidas sobre Meio Ambiente e Desenvolvimento, no Rio de Janeiro (ECO 92), muitos países signatários da Agenda 21 passaram a trabalhar reunidos no compromisso e no desafio de concretizar, em suas políticas públicas, as noções de sustentabilidade e de desenvolvimento sustentável com metas para a melhoria das condições ambientais do planeta.

No fórum internacional de Johanesburgo, de 2002 (Rio +10), com a denominação de Cúpula Mundial sobre o Desenvolvimento Sustentável, a ONU anunciou um conjunto de metas com vistas à redução pela metade do número de pessoas que vivem abaixo da linha da pobreza, bem como de questões importantes sobre fornecimento de água, energia, saúde, agricultura e biodiversidade.

Dessarte, o desenvolvimento se apoia e deve observância aos novos paradigmas e aos novos valores no domínio da economia concebida como de livre mercado, integrando-se, para tanto, com as dimensões social, ambiental e institucional, ao que é chamado desenvolvimento sustentável para a qualidade de vida das presentes e futuras gerações.

Sendo assim, o direito ao desenvolvimento sustentável configura um direito humano fundamental tanto no aspecto individual como no aspecto coletivo, pois cada ser humano, bem como a humanidade inteira, deve ter acesso tanto às condições de desenvolvimento quanto a um ambiente ecologicamente equilibrado e saudável.

\section{A CRIAÇÃO E IMPORTÂNCIA DO DIREITO FRATERNO NO CONTEXTO MUNDIAL}

\subsection{DiReITOS FUndaMENTAIS E DIREITOS HUMANOS}

A proteção de determinados direitos intrínsecos do ser humano é denominada de várias maneiras no decorrer da história da humanidade, tais como:

10 BENJAMIN, Antônio Herman V. Introdução ao direito ambiental brasileiro. Revista de Direito Ambiental, São Paulo: RT, n. 14, p. 48, abr./jun. 1999. 
"direitos fundamentais", "direitos humanos", "direitos humanos fundamentais", "direitos do homem", enfim, diversas nomenclaturas apresentadas por juristas, doutrinadores e cientistas. A busca de um conceito ou a pormenorizada diferença entre denominações de "direitos humanos" e "direitos fundamentais" baseia-se que são nomenclaturas complementares, mas não podem ser confundidas.

Os direitos fundamentais, nas palavras do constitucionalista Paulo Bonavides ${ }^{11}$, "são aqueles que o ordenamento jurídico qualifica como tais, ou seja, aqueles que foram reconhecidos pela ordem constitucional de um país. Essa noção de direitos fundamentais compreende além dos componentes jurídicos, pressupostos éticos". Ainda, reforça Canotilho que "os direitos fundamentais são aqueles direitos do ser humano reconhecidos e protegidos como tais pela ordem constitucional de um Estado. Assim, tratam-se de normas jurídicas vinculativas, protegidas através de controle jurisdicional da constitucionalidade dos dispositivos reguladores destes direitos"12.

Tais direitos, ao serem colocados e sopesados como forma pilar de um sistema jurídico, sob a proteção da Carta Fundamental de uma nação, diferenciaram dos chamados direitos humanos, reconhecidos internacionalmente ao ser humano considerado em si, mas, nos dizeres de Lorenzetti ${ }^{13}$, sem qualquer vinculação estatal e, muitas das vezes, não efetivados, onde certas declarações de direitos tomam a feição de meras cartas de intenções.

Conforme analisa Canotilho,

a positivação de direitos fundamentais significa a incorporação na ordem jurídica positiva dos direitos considerados naturais e inalienáveis do indivíduo. Não basta qualquer positivação. É necessário assinalar a dimensão de fundamental colocados no lugar cimeiro das fontes do direito: as normas constitucionais. Sem esta positivação jurídica, os direitos do homem são esperanças, aspirações, idéias, impulsos, ou, até, por vezes, mera retórica política, mas não direitos protegidos sob a forma de normas (regras e princípios) de direito constitucional (Grundreschtsnormen). ${ }^{14}$

Na grande maioria dos textos constitucionais normativos internacionais, vários dos direitos humanos já conhecidos são implementados naqueles. O que não quer dizer que haja uma identidade entre as normatizações, podendo haver uma maior ou menor incidência de proteção junto aos ordenamentos jurídicos de cada nação. Evidentemente, quanto maior incidência e manto constitucional

11 BONAVIDES, Paulo. Curso de direito constitucional. 12. ed. São Paulo: Malheiros, 2002. p. 514 e ss.

12 CANOTILHO, José Joaquim Gomes. Direito constitucional e teoria da constituição. 4. ed. Coimbra: Almedina, 2000. p. 372.

13 "A Declaração Universal dos Direitos Humanos, de 10.12.1948, dispunha que todos os seres humanos nascem livres e iguais em dignidades e direitos. O sujeito dos direitos é o ser humano e dos direitos são direitos humanos, porque todos os indivíduos deles são titulares, independentemente das questões de raça, nacionalidade, idade ou crença." (LORENZETTI, Ricardo Luiz. Fundamentos de direito privado. Trad. Véra Maria Jacob de Fradera. São Paulo: RT, 1998. p. 152)

Canotilho, op. cit., p. 371. 
que se der a tais direitos, maior possibilidade de efetivação e consagração como fundamentais tais direitos terão.

Na mesma linha de pensamento ressalta Gregório Robles:

Os direitos fundamentais são determinados positivamente. São direitos humanos positivados, isto é, concretados e protegidos especialmente por normas do nível mais elevado. A positivação tem tal transcendência que modifica o caráter dos critérios morais em autênticos direitos subjetivos dotados de maior proteção que os direitos subjetivos não fundamentais. ${ }^{15}$

A necessária e quase obrigatória efetivação dos direitos fundamentais nos ordenamentos jurídicos se torna uma busca da universalização dos direitos em contraponto a relativização daqueles.

Em a Era dos direitos, Noberto Bobbio confirma o dito acima "o problema fundamental em relação aos direitos do homem, hoje, não é tanto o de justificá-los, mas de protegê-los [...] o problema que temos diante de nós não é filosófico, mas jurídico e, num sentido mais amplo, político" ${ }^{\prime 16}$, ou seja, à efetivação dos direitos fundamentais encontra obstáculos e barreiras não em sua previsão nos textos normativos, mas na objetiva concretização das regras já existentes.

Reforça ainda Canotilho: "Direitos fundamentais referem-se aqueles direitos inerentes ao homem como indivíduo ou como participante na vida política; as liberdades, à defesa da esfera jurídica dos cidadãos perante os poderes adequados para a defesa dos direitos" ${ }^{\prime 17}$.

\subsection{Solidariedade social no Direito brasileiro}

De acordo com a Constituição da República de 1988, nos ensinamentos de Alexandre de Morais, os direitos e as garantias fundamentais se subdividem em: direitos individuais e coletivos, direitos sociais, direitos de nacionalidade, direitos políticos e direitos relacionados à existência, organização e participação em partidos políticos ${ }^{18}$.

A Constituição brasileira consagrou o direito fundamental em todos as garantias relacionadas anteriormente por Moraes; porém, não se pode esquecer do direito fundamental ao meio ambiente ecologicamente equilibrado, previsto no art. 225 da CR/1988 e, principalmente, não somente o direito, mas o dever de não degradar, de proteger e preservar o meio ambiente, com viés em um desenvolvimento sustentável. A nossa Carta Maior adota um duplo viés protetivo,

15 ROBLES, Gregório. Os direitos fundamentais e a ética na sociedade atual. Trad. Roberto Barbosa Alves. Barueri: Manole, 2005. p. 7.

16 Bobbio, op. cit., p. 43-45.

17 Canotilho, op. cit., passim.

18 MORAES, Alexandre de. Direitos humanos fundamentais: teoria geral. Comentários aos artigos $1^{\circ}$ a $5^{\circ}$ da Constituição da República Federativa do Brasil, doutrina e jurisprudência. 4. ed. São Paulo: Atlas, 2002. p. 43-44. 
com dimensão individual e coletiva: a) meio ambiente para assegurar a dignidade da pessoa humana para presentes e futuras gerações e a busca da preservação da natureza em suas formas variadas; e b) proteção ao desenvolvimento econômico sustentável ${ }^{19}$. Tais premissas para assegurar a fraternidade em todos os meios possíveis. É isto que afirma Fábio Konder Comparato ${ }^{20}$ :

são dois fatores de solidariedade humana: um de ordem técnica, transformador dos meios ou instrumentos de convivência, mas indiferente aos fins [...] que traduz pela padronização de costumes e modos de vida, pela homogeneização universal das formas de trabalho, de produção e troca de bens, pela globalização dos meios de transporte e comunicação [...] o outro, de natureza ética, procurando submeter a vida social ao valor supremo da justiça (trata-se da) solidariedade ética, fundada sobre o respeito aos direitos humanos, estabelece as bases para a construção de uma cidadania mundial, em que já não há relações de dominação, individual ou coletiva. São formas de solidariedade complementares e indispensáveis para que o movimento de unificação do gênero humano não sofra interrupção ou desvio.

Assim, é previsto na Constituição brasileira um "pacto" constitucional de proteção ao meio ambiente, tanto por parte do Poder Púbico como pela coletividade. É um verdadeiro poder geral de cautela ambiental, onde a coletividade com o compromisso de não degradação e prevenção, por meio de condutas comissivas e omissivas, buscará manter o sadio meio ambiente para o desenvolvimento das atividades humanas.

Ao garantir direitos ao meio ambiente para as "presentes e futuras gerações", ressalte-se que essa defesa se dá por vários prismas de atuação, isso demonstra a dimensão social que o termo tomou. Mas, na implementação desses direitos, devemos sempre indagar: Qual a real necessidade das presentes e futuras gerações? Quando tais necessidades não irão colidir com outros direitos fundamentais? E a hierarquia de direitos, qual prevalecerá?

Robert Alexi já afirmava em sua obra:

Não há hierarquia ente direitos. A institucionalização dos Direitos Fundamentais não resolve todos os problemas. O direito passa a ocupar o escalão hierárquico supremo no Ordenamento Jurídico, razão pela qual ele passa a ter força de concretização suprema ao lado de outros direitos consagrados como exame exegético de proporcionalidade que deve buscar a medida máxima de sua concretização quando ocorrer colisão entre tais direitos. ${ }^{21}$

19 A Comissão Mundial Sobre Meio Ambiente e Desenvolvimento (Nosso futuro comum. 2. ed. Rio de Janeiro: Fundação Getúlio Vargas, 1991. p. 46), ao relatar sobre o Relatório Brundtland sobre o tema Desenvolvimento sustentável: "Aquele que atende às necessidades do presente sem comprometer a possibilidade de as gerações futuras atenderem as suas próprias necessidades. Ele contém dois conceitos chave: conceito de necessidades, sobretudo as necessidades essenciais dos pobres do mundo, que devem receber a máxima prioridade; a noção das limitações que o estágio da tecnologia e da organização social impões no meio ambiente, impedindo-o de atender as necessidades presentes e futuras".

20 COMPARATO, Fábio Konder. A afirmação histórica dos direitos humanos. 2. ed. São Paulo: Saraiva, 2010.

21 ALEXY, Robert. Direitos fundamentais no Estado Constitucional Democrático: para a relação ente direitos do homem, direitos fundamentais, democracia e jurisdição constitucional. Revista de Direito Administrativo, v. 217, p. 55-66, jul./set. 1999. 
A conclusão que se refere a ponderação de interesses, então, é que o meio ambiente é força motriz de todos os direitos fundamentais, pois salvaguarda aspectos para a existência da própria vida.

Oportuna a confirmação do aventado anteriormente pelo Professor José Afonso da Silva,

a qualidade do meio ambiente em que a gente vive, trabalha e se diverte influi consideravelmente na própria qualidade de vida. O meio ambiente pode ser satisfatório e atrativo, e permitir o desenvolvimento individual, ou pode ser nocivo, irritante e atrofiante. [...] a qualidade do meio ambiente transforma-se, assim, num bem ou patrimônio, cuja preservação, recuperação ou revitalização se tornou num imperativo do Poder Público, cuja preservação, assegurar uma boa qualidade de vida que implica boas condições de trabalho, lazer, educação, saúde, segurança, enfim, boas condições de bem-estar do homem e de seu desenvolvimento. ${ }^{22}$

Como direito fundamental que é a solidariedade ou, pela Revolução Francesa, fraternidade, ao ser tratada como dimensão de direitos, reafirma que na história da humanidade os direitos não foram recriados, mas necessariamente insurgidos por não concordarem mais, aqueles que dele o utilizam, de tanta desigualdade e diferenças, mesmo sabendo que em seu mangedouro se tem uma série de documentos e pactos históricos com o fim único de se manter a configuração e a busca de um direito fraterno e comum. Consoante Rawls,

em comparação a liberdade e a igualdade, a fraternidade tem ocupado um lugar menos importante na teoria democrática. Considera-se que ela é um conceito menos especificamente político, que não define em si mesmo nenhum dos direitos democráticos, mas que em vez disso, expressa certas atitudes mentais e formas de conduta sem as quais perderíamos de vista os valores expressos por esses direitos. [...]. Algumas vezes se considera que o ideal de fraternidade envolve laços sentimentais que, entre membros da sociedade mais ampla, não seria realista esperar. E essa é certamente mais uma razão para que ele seja relativamente negligenciado na doutrina democrática. ${ }^{23}$

\section{Para Resta, o direito fraterno}

[...] trata-se de um modelo de direito que abandona a fronteira fechada da cidadania e olha em direção à nova forma de cosmopolitismo que não é representada pelos mercados, mas pela necessidade universalista de respeito aos direitos humanos que vai se impondo ao egoísmo dos "lobos artificiais" ou dos poderes informais que à sua sombra governam e decidem. ${ }^{24}$

O meio ambiente é identificado, então, como um direito fundamental de terceira geração, de fraternidade, por estar diretamente relacionado com a

22 SILVA, José Afonso da. Direito ambiental constitucional. 2. ed. São Paulo: Malheiros, 1997. p. 6.

23 RAWLS, John. Uma teoria da justiça. 2. ed. Trad. Almiro Pisetta e Lenita Maria Rímoli Esteves. São Paulo: Martins Fontes, 2002. p. 112-113.

24 RESTA, Eligio. O direito fraterno. Trad. Sandra Regina Martini Vial. Santa Cruz do Sul. Edunisc, 2004. 
qualidade de vida. Para Alexy, um direito fundamental é um "derecho fundamental como un todo" 25 , e, para o constitucionalista Manoel Gonçalves Ferreira Filho, "de todos os direitos da terceira geração, sem dúvida, o mais elaborado é o direito ao meio ambiente" ${ }^{26}$.

A afirmação de que proteger o meio ambiente é proteger direitos fundamentais, onde o Poder Público e cidadão se tornam ambos titulares de um dever, de um defender e de um preservar o meio ambiente, é tamanha que nossos Tribunais, em seus julgados, já tem percebido que a cooperação de terceira dimensão já é primordial em suas decisões quando há colisão de direitos entre o tema meio ambiente e outros direitos fundamentais, onde o jurisdicional procura sopesar e equipar o desenvolvimento à sustentabilidade. E mais, percebe ao julgar não somente causas ambientais, mas, em outras matérias, o princípio da solidariedade está intimamente atrelado à noção de direitos humanos e fundamentais.

\section{POLÍTICAS PÚBLICAS DE SUSTENTABILIDADE}

\subsection{Políticas públicas - Análise conceitual}

O termo "políticas públicas" pode ser conceituado como as políticas estatais que visem ao escopo de cumprir para atender o bem público sempre pela via do direito, com assistência àqueles setores da população, especialmente aos mais desfavorecidos e aos trabalhadores.

Seguindo os ensinamentos de Faleiros ${ }^{27}$, tem-se que as políticas sociais do Estado não são instrumentos de um bem-estar abstrato, não são medidas boas em si mesmas, também não são medidas más em si mesmas, como alguns apologistas de esquerda soem em dizer, afirmando que as políticas sociais são instrumentos de manipulação e de pura escamoteação da realidade da exploração da classe operária.

Em busca de promover o bem-estar social, o Estado necessita desenvolver uma série de ações e atuar diretamente em diferentes áreas, tais como saúde, educação, meio ambiente, utilizando-se das chamadas políticas públicas, que atualmente podem ser definidas da seguinte forma: "[...] Políticas Públicas são um conjunto de ações e decisões do governo, voltadas para a solução (ou não) de problemas da sociedade [... $]^{\prime 28}$.

25 Alexy, op. cit., p. 429.

26 FERREIRA FILHO, Manoel Gonçalves. Direitos humanos fundamentais. Curso de direito constitucional. 27. ed. atual. São Paulo: Saraiva, 2001. p. 62.

27 FALEIROS, Vicente. A política social do Estado capitalista. As funções da previdência e da assistência sociais. 5. ed. São Paulo: Cortez, 1987. p. 55.

28 CALDAS, Ricardo Wahrendorff (Coord.). Políticas públicas: conceitos e práticas. Belo Horizonte: Sebrae/MG, 2008. Disponível em: <http://www.portaldodesenvolvimento.com.br/conceitos-basicos/81-politicaspublicas/123-conceitos-de-politicas-publicas>. Acesso em: 25 abr. 2012. 
A Desembargadora Relatora Vera Andrisani, da $2^{\text {a }}$ Câmara de Direito Público do Tribunal de Justiça do Estado de São Paulo, assim se manifestou no Al 540.089-5/1-00:

O bem social é o interesse público primário por isso a vida e a saúde são merecedoras de especial proteção do ente e, para tanto, é certo que cave a Administração Pública diante de pacientes que não reúnam condições econômicas financeiras para arcar com o custeio da aquisição do remédio, suportar certas despesas porque estas são de sua responsabilidade.

O que é de caráter fraterno e igualitário para a sociedade é o equivalente à política pública. O igual para a população corresponde àquilo que é essencial, ou seja, sem aquilo não há como estabelecer uma sociedade cooperativa, nos moldes do desejado pela Revolução Francesa, sonhada de forma justa e desenvolvida.

A política, seja brasileira ou em âmbito internacional, deve estar direcionada para o cumprimento de direitos fundamentais, os quais são essenciais e comuns a toda uma sociedade. Ou seja, falar em políticas públicas é falar em democracia.

Faz-se mister ressaltar o entendimento hoje dominante de que o chamado bem-estar da sociedade é sempre definido pelo Governo e não pela sociedade propriamente dita, pois tem-se que esta não consegue expressar-se de forma integral, sendo possível apenas fazer solicitações a seus representantes para que estes mobilizem os membros do Poder Executivo (e também Legislativo e/ou Judiciário) e procurem atender as demandas da população.

Neste sentido, importa ressaltar a distinção entre políticas de Governo e políticas de Estado. A política de Governo é a praticada em prol dos interesses somente de quem está no poder (eventual e reflexamente, pode beneficiar grupos sociais fora do eixo governamental). Já política de Estado é a praticada em prol dos interesses supremos e maiores de um Estado, independentemente se irá favorecer ou não o interesse de quem está no poder naquele momento.

Maria Paula Dallari Bucci ${ }^{29}$ relata a dificuldade em se estabelecer um conceito jurídico para as políticas públicas:

Embora estejamos raciocinando há algum tempo sobre a hipótese de um conceito de políticas públicas em direito, é plausível considerar que não haja um conceito jurídico de políticas públicas. Há apenas um conceito que serve aos juristas (e aos não juristas) como guia para o entendimento das políticas públicas e o trabalho nesse campo. Não há propriamente um conceito jurídico, uma vez que as categorias que estruturam o conceito são próprias ou da política ou da Administração Pública. Entretanto, se não há um conceito jurídico, deve haver, com certeza, uma metodologia jurídica. As tarefas dessa são descrever, compre-

29 BUCCI, Maria Paula Dallari. O conceito de políticas públicas em direito. In: BUCCI, Maria Paula Dallari (Org.). Políticas públicas: reflexões sobre o conceitos jurídico. São Paulo: Saraiva, 2006. p. 47. 
ender e analisar as políticas públicas, de modo a conceber as formas e processo jurídicos correspondentes. Mas isso é assunto para um outro estudo.

Assim, o interesse público reflete as demandas e expectativas da sociedade, formando-se a partir da atuação dos diversos grupos, mediante a apresentação de reivindicações e tentativa de obtenção de apoio de outros grupos.

Sendo assim, Palmeira e Lechner ${ }^{30}$ caracterizam o termo "política pública" aquela que visa a assegurar o redirecionamento da sociedade, isto é, garantir que as mutações por ela geradas propiciem o bem-estar do conjunto de sua população. Tem, portanto, mais do que paliativa, uma natureza preventiva e organizativa da sociedade.

Dalmo de Abreu Dallari apresenta o Estado como uma ordem jurídica soberana, cuja finalidade é o bem comum do povo situado em determinado território, dispondo acerca desta finalidade:

[...] podemos concluir que o fim do Estado é o bem comum, entendido este como conceituou o Papa João XXIII, ou seja, o conjunto de todas as condições de vida social que consintam e favoreçam o desenvolvimento integral da personalidade humana. [...] existe uma diferença fundamental, que qualifica a finalidade do Estado: este busca o bem comum de um certo povo, situado em determinado território. Assim, pois o desenvolvimento integral da personalidade dos integrantes desse povo é que deve ser o seu objetivo, o que determina uma concepção particular de bem comum para cada Estado, em função das peculiaridades de cada povo. ${ }^{31}$

A finalidade estatal deve compreender as necessidades de seu povo, que assegurarão uma existência digna em respeito ao princípio da dignidade da pessoa humana. Tais necessidades buscam representar o conjunto de bens e serviços para a satisfação humana de 3 (três) formas ou espécies: individuais, coletivas e públicas.

\section{No entender de Dejalma de Campos,}

as necessidades individuais são aquelas satisfeitas pelo esforço do próprio indivíduo, tais como: alimentação, vestuário, habitação, e etc.; as necessidades coletivas, por sua vez, são satisfeitas pelo esforço coordenado da sociedade, a saber: as necessidades de escolas particulares, de oficinas mecânicas, de transportes coletivos, etc. e, finalmente, as necessidades públicas são tuteladas pelo Estado que toma para si a responsabilidade pela sua efetivação, destacando-se: a manutenção da ordem pública, a defesa nacional, a proteção da ordem interna, a proteção da saúde pública, a previdência social, a proteção trabalhista, entre outras. $^{32}$

30 PALMEIRA, Maria José; LECHNER, Franck. As mutações sociais e as políticas públicas. Disponível em: <www.cedeca.org.br/PDF/mutações_maria_palmeira.pdf>. Acesso em: 25 abr. 2012.

31 DALLARI, Dalmo de Abreu. Elementos de teoria geral do Estado. 21. ed. atual. São Paulo: Saraiva, 2000. p. 107.

32 CAMPOS, Dejalma de. Direito financeiro e orçamentário. São Paulo: Atlas, 1995. p. 21. 
Apesar da finalidade do Estado ser o atendimento do bem comum do seu povo, ele não dispõe de recursos financeiros suficientes para a satisfação de todas as necessidades existentes, tendo, então, que implementar, mediante uma escolha ou decisão política de seus governantes, as necessidades que julgar mais pertinentes e adequadas para aquela determinada comunidade. Celso Bastos explica que

a atividade pública não consegue satisfazer a todas as necessidades coletivas. Essa é a razão da inevitabilidade da intermediação de uma escolha feita pelos governantes, que optam dentre as necessidades coletivas por aquelas que merecem satisfação por meio de uma atividade pública.

O Estado não deixa de ser uma grande associação. Enquanto tal existe para o atingimento de certos fins que dizem respeito aos interesses da própria coletividade, é a atividade política que determina a escolha dos objetivos que devem ser perseguidos prioritariamente, visto que não é possível querer-se atingi-los, a todos, simultaneamente. [...] O importante é reconhecer-se que o funcionamento do Estado conduz, necessariamente, a existência de uma atividade financeira consistente na obtenção de recursos, na sua gestão e, ao final, na sua aplicação. É uma atividade, sem dúvida, importante porque torna possível a existência das demais.

Sabe-se que são hoje muitos dos fins colimados pelo Estado: manutenção da ordem interna, asseguramento da defesa contra eventual inimigo externo, aplicação do Direito aos casos controvertidos (distribuição da justiça), feitura das leis que regerão a comunidade, prestação de serviços públicos, construção de estradas, fiscalização de muitas atividades particulares, e até mesmo no campo social e econômico a presença do Estado faz-se sentir de forma acentuada. ${ }^{33}$

Com o desenvolvimento da sociedade, tornou-se imperioso que a função social desempenhada pelo Estado sofresse inúmeras transformações ao passar do tempo, tendo a finalidade de se adequar às novas necessidades advindas das transformações sociais.

Como exemplo, observa-se que, nos séculos XVIII e XIX, o principal objetivo estatal era a segurança pública e a defesa externa em caso de ataque estrangeiro (inimigo). Ocorre que, na medida em que houve o aprofundamento e a expansão da democracia, as responsabilidades do Estado se diversificaram, sendo comum se afirmar que, na atualidade, a função do Estado é promover o bem-estar da sociedade.

Enquanto área de conhecimento e disciplina acadêmica o termo "políticas públicas", nasce, nos EUA, sem estabelecer relações com as bases teóricas sobre o papel do Estado, passando direto para a ênfase nos estudos sobre a ação dos Governos. 
Os problemas sociais surgem em vários aspectos, quer seja o setor da saúde, da educação, do lazer, do transporte, quer seja o setor ambiental, o qual reflete diretamente na saúde e no bem-estar da população.

Em meio a tais situações problemáticas, o Estado busca meios de fornecer saúde, educação, transporte, lazer e, principalmente, garantir um meio ambiente saudável àqueles menos favorecidos (sobremaneira nos aspectos social e econômico).

Dessa forma, trata-se de uma necessidade decorrente da era pós-Revolução Industrial, quando se fortaleceu o capitalismo, bem como se ampliou os extremos de riqueza e pobreza, fazendo-se necessário que o Estado, mediante as necessidades e os clamores sociais, criasse políticas públicas que amparassem os menos favorecidos e evitasse o caos social causado pela extrema distância entre os miseráveis e abastados.

\subsection{SUSTENTABILIDADE}

\subsubsection{Conceito}

Sustentabilidade é a habilidade, no sentido de capacidade, de sustentar ou suportar uma ou mais condições, atualmente configuradas na produção industrial concomitante à manutenção do meio ambiente equilibrado.

Tal conceito cada vez mais se torna um princípio configurado no o uso dos recursos naturais para a satisfação de necessidades presentes de forma equilibrada para não comprometer a satisfação das necessidades das gerações futuras, evitando-se o esgotamento dos recursos naturais.

O termo "sustentável" provém do latim sustentare (sustentar; defender; favorecer, apoiar; conservar, cuidar). Segundo o Relatório de Brundtland (1987), o uso sustentável dos recursos naturais deve "suprir as necessidades da geração presente sem afetar a possibilidade das gerações futuras de suprir as suas".

\subsubsection{Origem}

As discussões acerca do termo começaram na Conferência das Nações Unidas sobre o Meio Ambiente Humano (United Nations Conference on the Human Environment - UNCHE), realizada em Estocolmo de 5 a 16 de junho de 1972.

Em seguida, ocorreu a Conferência de Estocolmo, a qual lançou as bases das ações ambientais em nível internacional e foi responsável por chamar a atenção internacional para questões relacionadas com a degradação ambiental e a poluição.

A Declaração de Estocolmo definiu princípios de preservação e melhoria do ambiente natural, destacando a necessidade de apoio financeiro e assistência técnica a comunidades e países mais pobres. 
A ECO-92, Conferência sobre Meio Ambiente e Desenvolvimento, realizada em 1992, no Rio de Janeiro, consolidou o conceito sustentabilidade, colocando os termos meio ambiente e desenvolvimento juntos e concretizando a possibilidade apenas esboçada na Conferência de Estocolmo, em 1972, consagrando o uso do conceito de desenvolvimento sustentável, defendido, em 1987, pela Comissão Mundial sobre Meio Ambiente e Desenvolvimento (Comissão Brundtland).

Anderson ${ }^{34}$ acrescenta que o termo "sustentabilidade" passou a ser entendido como o desenvolvimento que atende às necessidades do presente, sem comprometer a possibilidade das futuras gerações de atenderem às suas próprias.

Em 2002, a Cimeira (ou Cúpula) da Terra sobre Desenvolvimento Sustentável de Johanesburgo reafirmou os compromissos da Agenda 21, propondo a maior integração das três dimensões do desenvolvimento sustentável (econômica, social e ambiental) por meio de programas e políticas centrados nas questões sociais e, particularmente, nos sistemas de proteção social.

\subsubsection{Dimensões do termo sustentabilidade}

Silva ${ }^{35}$ afirma que o termo "sustentabilidade" possui cinco dimensões: a ecológica, a cultural, a espacial, a social e a econômica.

A sustentabilidade social pode ser entendida como a tentativa de se criar um processo de desenvolvimento amparado por uma civilização com maior equidade na distribuição de renda e de bens, visando à redução do abismo entre os padrões de vida dos ricos e dos pobres.

Assim, o Governo tenta minimizar a ampla desigualdade social, fornecendo aos menos favorecidos benefícios que estes não teriam acesso se não fosse a atuação estatal, tais como o acesso à saúde, à educação e ao transporte.

A sustentabilidade econômica busca o gerenciamento e a alocação mais eficiente possível dos recursos e de um fluxo constante de investimentos públicos e privados. O Governo Federal, por exemplo, estabelece quais as áreas que mais necessitam de recursos públicos e, por meio da arrecadação global (e também de Estados mais ricos e produtivos), direciona os recursos econômicos a Estados mais pobres e com produção mais baixa, na tentativa de se fazer uma justiça social por meio da distribuição de renda entre os entes da federação.

A sustentabilidade ecológica visa à utilização de recursos renováveis e menos esgotáveis, tentando preservar os recursos naturais não renováveis e fa-

34 ANDERSON, Perry. Balanço do neoliberalismo. In: SADER, Emir; GENTILI, Pablo (Org.). Pós-neoliberalismo. As políticas sociais e o Estado Democrático. Rio de Janeiro: Paz e Terra, 1998.

35 SILVA, Geraldo Eulálio do Nascimento. Direito ambiental internacional: meio ambiente, desenvolvimento sustentável e os desafios da nova ordem mundial. Rio de Janeiro: Thex, 1995. 
cilmente esgotáveis. Por exemplo: tenta-se limitar o consumo de combustíveis fósseis e de outros recursos e produtos que são facilmente esgotáveis e estimular a respectiva substituição pelo consumo de combustíveis renováveis decorrentes da água, do álcool, da energia eólica ou mesmo solar.

A sustentabilidade espacial é caracterizada pelo melhor direcionamento na ocupação das regiões urbanas e rurais, com vistas à melhor distribuição dos assentamentos, de forma a não degradar o meio ambiente e não prejudicar o desenvolvimento tecnológico-industrial, bem como a melhoria de vida da população.

A sustentabilidade cultural procura a valorização das raízes endógenas relacionadas aos processos de modernização e de sistemas agrícolas integrados, que facilitem a geração de soluções específicas para o local, o ecossistema, a cultura e a área. Assim, busca-se o desenvolvimento tecnológico em harmonia às características culturais da população, bem como às características do meio ambiente ocupado pelo respectivo setor social.

A busca de sustentabilidade é um processo, sendo necessária a conscientização dos Governos e de suas respectivas populações, com vistas a se evitar o esgotamento dos recursos naturais e se garantir a continuidade do desenvolvimento tecnológico e social para as gerações futuras, mediante o desenvolvimento e a aplicação atuante das políticas públicas de sustentabilidade.

\subsubsection{Implementação de políticas públicas de sustentabilidade no Brasil}

Antes de serem apresentadas algumas políticas públicas relacionadas à sustentabilidade, há de se ressaltar as dimensões jurídicas das políticas públicas na realização dos direitos humanos.

Segundo Comparato ${ }^{36}$, a partir do Pacto Internacional sobre Direitos Econômicos, Sociais e Culturais, a posição do Estado passou do polo passivo para o ativo da relação jurídica, tendo em vista que, anteriormente, cabia ao Estado manter-se inerte e não violar os direitos e as liberdades civis e políticas dos cidadãos.

Como já mencionado, a partir de meados do século XX, o Estado passa a atuar ativamente na elaboração de políticas públicas ou programas de ação governamental para implementação e efetivação dos direitos humanos de conteúdo econômico, social e cultural, bem como da garantia de um desenvolvimento sustentável, concretizando as políticas públicas de sustentabilidade.

Cabe destacar que a realização de políticas públicas pressupõe a relação combinada entre Estado e sociedade civil (agentes econômicos, organizações civis e particulares), dando real significado à democracia participativa. 
Como exemplo de política pública de sustentabilidade já implementada no Brasil tem-se que o Governo Federal, por meio do Plano de Ação para Prevenção e Controle do Desmatamento da Amazônia Legal, apresentou um conjunto de ações estratégicas, consideradas prioritárias por sua relevância para a contenção do desmatamento na Amazônia Legal, bem como para a viabilização de estratégias alternativas de proteção e uso sustentável da floresta, mediante o Decreto de 3 de julho de 2003.

O mencionado plano de ação previa o fomento às atividades sustentáveis, mediante o aperfeiçoamento de instrumentos de financiamento e créditos existentes, que utilizam recursos públicos para promover atividades produtivas sustentáveis e desestimular o desmatamento ilegal.

Previa, também, desenvolver e implementar o programa de capacitação, formação e divulgação do manejo florestal sustentável; apoiar as comunidades extrativistas e indígenas; o fomento ao ecoturismo; implantar e consolidar os polos pioneiros de produção familiar sustentável; apoiar o desenvolvimento sustentável da cadeia produtiva de madeira e móveis; implementar as ações para uma política agrícola sustentável para a Amazônia Legal; e adotar como exigência básica para os produtores rurais contemplados nos programas e nas ações do Ministério da Agricultura, da Pecuária e do Abastecimento o cumprimento da legislação ambiental.

Na esfera internacional, o Governo brasileiro tem defendido "que a comunidade internacional estabeleça uma verdadeira política pública mundial da alimentação e de agricultura". Para isso, foi celebrada uma "parceria global para a agricultura, a segurança alimentar e a nutrição", que foi criada a partir do Comitê de Segurança Alimentar da $\mathrm{FAO}^{37}$.

Os exemplos supra permitem observar que é possível a implementação de políticas públicas de sustentabilidade.

Ocorre que, até agora, os Governos (nacional e internacional) têm agido de forma tímida e pontual, o que ainda não é o bastante frente à crescente e preocupante degradação ambiental que pode comprometer a sobrevivência saudável das gerações futuras.

\section{DOCUMENTO “OUR COMMNON FUTURE” E O DESENVOLVIMENTO SUSTENTÁVEL DEFINIDO EM PLANO INTERNACIONAL}

O documento "Our Common Futre", também conhecido como Relatório Brundtland, da Organização das Nações Unidas da Comissão Mundial sobre Meio Ambiente e Desenvolvimento (WCED), foi publicado em 1987. O ponto focal do documento era o multilateralismo e a interdependência das nações, mediante o crescente desenvolvimento tecnológico e industrial, e a necessi- 
dade de compatibilizar tal crescimento com a busca de um desenvolvimento sustentável ${ }^{38}$.

Houve a tentativa de recuperação do espírito da Conferência das Nações Unidas a respeito do ambiente humano, caracterizada como Conferência de Estocolmo, na qual ficou claro que, em um futuro comum, seria crucial que as questões ambientais fossem colocadas firmemente sobre a agenda política, a fim de se discutir a manutenção do meio ambiente em harmonia com o desenvolvimento humano como um problema grave ${ }^{39}$.

A publicação de Nosso Futuro Comum e do trabalho da Comissão Mundial sobre Meio Ambiente e Desenvolvimento lançou as bases para a convocação, no ano de 1992, da Cimeira da Terra e da adoção da denominada Agenda 21, a Declaração do Rio e para o estabelecimento da Comissão sobre Desenvolvimento Sustentável.

Evidenciou-se que, em prol da evolução e do desenvolvimento da sociedade contemporânea, não é preciso comprometer a evolução e o desenvolvimento das gerações futuras, sendo necessário garantir a sobrevivência sadia dos descendentes das nações hodiernas para se evitar o fim do ecossistema e da humanidade.

\subsection{Análise do teor "Our Common Future"}

\subsubsection{Origem das discussões}

Em 1983, o Secretário-Geral da ONU convidou a primeira-ministra norueguesa Gro Harlem Brundtland para presidir uma Comissão Mundial sobre Meio Ambiente e Desenvolvimento em razão da preocupação com a forte pressão do crescimento populacional, a moderna tecnologia, bem como a demanda do consumidor sobre o tecido planetário, especialmente desde 1970.

Desde então, surgira uma nova geração de preocupações ambientais: aquecimento global, desmatamento, perda de espécies, resíduos tóxicos, em meio ao esgotamento rápido dos recursos naturais em nome do desenvolvimento.

Ocorre que, mesmo diante do crescente desenvolvimento, a pobreza também estava se difundindo assustadoramente, ampliando cada vez mais a distância entre os limiares da distribuição de renda.

Em 1987, a Comissão Brundtland havia entregue o seu relatório, intitulado "Our Common Future", mas, na época, o crescimento populacional não era mais visto como a principal ameaça para a harmonia do planeta, tendo em vista que tal crescimento incidia, na sua maior parte, entre os mais pobres, enquanto

38 Disponível em: <http://pt.wikipedia.org/wiki/Relat\%C3\%B3rio_Brundtland>. Acesso em: 29 abr. 2012.

39 Disponível em: <http://pt.wikipedia.org/wiki/Relat\%C3\%B3rio_Brundtland>. Acesso em: 29 abr. 2012. 
que os grandes industriais eram os maiores responsáveis pelo consumo excessivo de combustíveis fósseis, pelo aquecimento do globo com as suas emissões de carbono, envenenamento do solo e da água, com seus produtos químicos, bem como mediante estragos ecológicos, com vazamentos de petróleo, etc.

Assim, o conceito de "desenvolvimento sustentável" foi lançado tendo como grande desafio manter o avanço social e econômico para assegurar aos seres humanos uma vida saudável e produtiva, mas que não chegasse a comprometer a capacidade de as gerações futuras satisfazerem as suas próprias necessidades.

\section{DESENVOLVIMENTO ECONOMICAMENTE VIÁVEL E SOCIALMENTE JUSTO}

Como visto, o documento entende que o desenvolvimento sustentável pode ser caracterizado como aquele que satisfaz as necessidades do presente sem comprometer a capacidade de as gerações futuras satisfazerem as suas próprias necessidades. A novidade é que o documento "Our Common Future" contém, em si, conceito de necessidades, em particular as necessidades essenciais dos pobres do mundo, para os quais a prioridade absoluta deve ser dada ${ }^{40}$, bem como a ideia de limitações impostas pelo estado da tecnologia e da organização social sobre a capacidade do meio ambiente para atender às necessidades presentes e futuras.

O desenvolvimento global sustentável exige a mudança de atitude daqueles que têm mais acesso à tecnologia no sentido de adotarem estilos de vida dentro dos meios ecologicamente sustentáveis do planeta - em seu uso de energia, por exemplo.

As populações em rápido crescimento tendem a aumentar a pressão sobre os recursos naturais, assim o desenvolvimento sustentável só pode ser exercido se o ritmo de crescimento populacional estiver em harmonia com o potencial produtivo de alteração do ecossistema.

Sendo assim, segundo o documento "Our Common Future", o desenvolvimento configura um processo de mudança, no qual a exploração dos recursos, a direção dos investimentos, a orientação do desenvolvimento tecnológico, bem como a mudança institucional são coerentes com futuro ${ }^{41}$.

40 "Qualquer análise que se faça do estado do meio ambiente no Brasil - e, nisto, nada temos de diferente dos demais países do mundo - demonstrará que os principais problemas ambientais se encontram nas áreas mais pobres e que as grandes vítimas do descontrole ambiental são os mais desafortunados. De fato, há uma relação perversa entre condições ambientais e pobreza." (ANTUNES, Paulo de Bessa. Direito ambiental. 13. ed. rev. e atual. Rio de Janeiro: Lumen Juris, 2011. p. 27)

41 “[...] A administração do meio ambiente e a manutenção do desenvolvimento impõem sérios problemas a todos os países. Meio ambiente e desenvolvimento não constituem desafios separados; estão inevitavelmente interligados. $O$ desenvolvimento não se mantém se a base de recursos ambientais se deteriora; o meio ambiente não pode ser protegido se o crescimento não leva em conta as consequências da destruição ambiental. Esses problemas não podem ser tratados separadamente por instituições e políticas fragmentadas. Eles fazem parte 
Observa-se que os desafios são interdependentes e as soluções são integradas, exigindo abordagens abrangentes, bem como a participação de toda a sociedade.

No âmbito do direito pátrio, a positivação do princípio do desenvolvimento sustentável ocorreu no art. 225 da CRFB de 1988, no capítulo que trata do meio ambiente ${ }^{42}$.

\subsection{BINÔMIO CRESCIMENTO dA POPULAÇÃO E PRODUÇ̃̃o ALIMENTÍCIA}

Há o "problema populacional", o qual requer esforços para eliminar a pobreza em massa, de modo a garantir um acesso mais equitativo aos recursos planetários e melhorar o potencial humano para gerir tais recursos. Neste sentido, cresce a necessidade de desenvolvimento de políticas públicas que tenham objetivos demográficos gerais e específicos que visem a fortalecer as motivações sociais, culturais e econômicas em torno do planejamento familiar.

Verifica-se, também, a crescente produção mundial de cereais, a qual supera o crescimento da população mundial, sendo que, em contrapartida, a cada ano mais pessoas no mundo não recebem comida suficiente, concluindo-se que a agricultura mundial tem o potencial de produzir alimentos suficientes para todos, mas a comida não está frequentemente disponível onde é necessário.

Dessa forma, a questão da produção alimentícia exige atenção a elementos, como a distribuição e logística dos alimentos, bem como a distribuição de renda.

\subsection{DevastaÇão ambiental e a realidade enerGética}

Com relação à devastação ambiental, asseverou o documento em análise que a primeira prioridade é estabelecer o problema das espécies e ecossistemas ameaçados, discutindo-se uma agenda de políticas públicas voltada para a proteção da biodiversidade.

Outro aspecto importante seria a implementação de medidas que tratem da precaução e da prevenção de danos ambientais, bem como a promoção da utilização mais eficiente dos recursos a longo prazo das florestas, reduzindo o desmatamento.

de um sistema complexo de causa e efeito." (Comissão Mundial sobre Meio Ambiente e Desenvolvimento. Nosso futuro comum. Rio de Janeiro: FGV, 1988. p. 40)

42 " $[. .$.$] ao contrário da gênese dos demais direitos fundamentais, não foi a Constituição dos Estados que liderou o$ processo de tomada de consciência jurídica da existência de um direito humano ao meio ambiente, bem como a necessidade de proteção autônoma dos diversos ecossistemas e dos elementos biológicos, físicos e químicos que os integram. Foi o direito internacional, através de documentos como a Declaração de Estocolmo de 1972 e o Informe Brundtland de 1982, elaborado pela Comissão Mundial sobre Meio Ambiente e Desenvolvimento das Nações Unidas, que afirmou de forma irrefutável e pioneira a proteção do meio ambiente e a necessidade de que o desenvolvimento humano passasse a ser sustentável." (BONAVIDES, Paulo (Coord.); RODRIGUES, Geisa de Assis et al. Comentários à Constituição Federal de 1988. Rio de Janeiro: Forense, 2009. p. 2345) 
Com relação à preocupação de se buscar uma fonte energética mais segura e sustentável, o documento demonstrou que uma pessoa média em uma economia de mercado industrial emprega mais de 80 vezes mais energia do que alguém na África subsaariana, sendo que qualquer cenário energético global realista deve ter ciência de que o uso de energia primária aumentou substancialmente nos países em desenvolvimento.

Entretanto, para trazer o desenvolvimento da energia dos países menos industrializados ao nível dos países industrializados até o ano 2025, seria necessário multiplicar o consumo de energia global atual por um fator de 5 (cinco), o que causará impactos ambientais sem precedentes, caso não seja baseado na diversidade das fontes energéticas, com a ampliação do uso de fontes de energias renováveis sustentáveis (ERS's).

Em tal contexto, observa-se que qualquer nova era de crescimento econômico deve priorizar a utilização mais eficiente e racional de energia do que o crescimento no passado, mediante políticas de eficiência energética, respeitando-se os recursos naturais de cada nação e utilizando-se as fontes energéticas mais disponíveis e renováveis em cada ecossistema.

Ressalta-se que há muito espaço para melhorias nesse sentido, existindo aparelhos modernos, os quais podem ser redesenhados para oferecer a mesma quantidade de energia, serviços com apenas dois terços ou mesmo metade das entradas de energia primária necessária para fazer funcionar equipamentos tradicionais, respeitando-se as fontes energéticas características do ecossistema singular de cada nação, de forma a priorizar o mercado interno e evitar o esgotamento das fontes energéticas.

Deve ser dada prioridade à investigação e ao desenvolvimento de alternativas ambiental e ecologicamente viáveis, incrementando-se programas de pesquisa e financiamento necessário para assegurar o rápido desenvolvimento das energias renováveis, aplicando-se as políticas públicas de sustentabilidade também neste sentido.

\subsection{OS EFEITOS DA PRODUÇãO INDUSTRIAL}

Com relação ao ano de 1950, observa-se que o mundo produz, industrialmente, sete vezes mais hoje do que nessa data; entretanto, tal produção atende apenas a uma pequena parcela da população mundial em razão de fatores como a distribuição de renda.

Sendo assim, o que se presencia atualmente é um excesso de produção de itens supérfluos, que não atendem às necessidades humanas e ambientais. A questão é canalizar a produção para itens realmente úteis às pessoas e ao meio ambiente e a consequente melhoria na distribuição de renda para que os benefícios da produção industrial atendam ao maior número possível de pessoas. 
Neste diapasão, verifica-se que a experiência nas nações industrializadas provou que a tecnologia antipoluição tem sido rentável em termos de saúde, economia de mercado e evita danos ambientais, tornando muitas indústrias mais rentáveis, com políticas públicas que incentivem a produção industrial de forma sustentável, o que é possível também em países emergentes, pois estes estão cada vez mais abertos ao capital estrangeiro e podem se aliar a estes para incentivar a aplicação de tal tecnologia.

\section{A EFETIVAÇÃO DOS DIREITOS HUMANOS FUNDAMENTAIS NO JUDICIÁRIO BRASILEIRO E A ANÁLISE DA CLÁUSULA DE RESERVA DO POSSÍVEL}

Diante da realidade apresentada, em que o desenvolvimento está atrelado a questões socioeconômicas, há necessidade de um novo posicionamento jurídico com o intuito de resguardar as garantias fundamentais da geração presente e futura.

\section{Ensina Bonavides que,}

com a queda do positivismo, o centro de gravidade dos estudos constitucionais que antes, centravam-se na parte organizacional da Constituição, tem-se deslocado para o estudo dos direitos fundamentais e das garantias processuais. Sob essa perspectiva se deflagrou várias inovações constitucionais, dentre elas a concepção de uma dimensão axiológica dos direitos fundamentais, na medida em que aparecem como postulados sociais que exprimem uma determinada ordem de valores servindo de inspiração, impulso e diretriz para a legislação, administração e jurisdição. ${ }^{43}$

Como já analisado ao longo deste estudo, os direitos fundamentais surgiram de um Estado Constitucional, como consequência da evolução da humanidade. Os documentos históricos produzidos permeiam e concretizam um pilar de formação em que a história de tais direitos evidenciam, sim, a partir da construção de preceitos não só da história, mas de todo um processo de evolução dos Estados.

No que se refere ao nosso Poder Judiciário, este dá um tratamento sui generis às normas constitucionais. O tratamento legislativo aplicado pelo jurisdicionado se dará de acordo com a interpretação e análise efetiva para a função de concretização das normas constitucionais. Como ressalta Dworkin, "o objetivo da decisão judicial constitucional não é meramente nomear direitos, mas assegurá-los, e fazer isso no interesse daqueles que têm direitos" ${ }^{\prime 4}$.

Essa concretização de direitos e normas fundamentais tem baliza como função típica do julgador. Porém, não pode o Poder Judiciário exercer o ofício de julgar, ou efetivar direitos, se não disponibilizar de maneiras adequadas para tal.

43 BONAVIDES, Paulo. Curso de direito constitucional. 7. ed. São Paulo: Malheiros, 1997. p. 541.

44 DWORKIN, Ronald. O império do direito. São Paulo: Martins Fontes, 1999. p. 465. 
Ao proferir uma decisão, o Magistrado deve, com parcimônia, sopesar que o atendimento dos "direitos humanos", "direitos fundamentais" ou "direitos humanos fundamentais" está sujeito não à liberdade de decidir, mas a um limite, presente na própria lei fundamental, o que convencionou denominar de cláusula de reserva do possível" ou do "financeiramente possível".

Essa cláusula limita a atuação de concretização de normas fundamentais por demandarem a adoção de políticas públicas, consideradas, muitas das vezes, de certa complexidade.

Originário do Direito alemão, a cláusula de "reserva do possível" (Der Vorbehalt dês Möglichen), que começou a ser alegada a partir da década de 1970, é criação do Tribunal Constitucional alemão e compreende a possibilidade material (financeira) para prestação dos direitos sociais por parte do Estado, uma vez que tais prestações positivas são dependentes de recursos presentes nos cofres públicos. A partir daí, alguns autores vão defender que as aplicações desses recursos e, consequentemente, a implementação de medidas concretizadoras de direitos sociais seria uma questão restrita e limitada à esfera de discricionariedade das decisões governamentais e parlamentares, sintetizadas nos planos de políticas públicas destes e conforme as previsões orçamentárias.

A partir de uma exemplificação de um case decidido pelo Tribunal Federal alemão (numerus clausus) ${ }^{45}$, proporcionou ao indivíduo exigir o cumprimento daquilo que minimamente seria razoável exigir-se do Estado dentro dos limites do razoável.

Andréas Krell ${ }^{46}$ relata que

a leitura da reserva do possível é "falaciosa", pois se os recursos são incontroversamente reconhecidos como insuficientes, devemos retirá-los de áreas menos importantes do ponto de vista do interesse público (transporte, fomento) para aplicar em outras mais essenciais (vida, integridade física, saúde).

\section{Já Alexy defende}

o reconhecimento da liberdade de configuração do legislador democrático na seleção das áreas nas quais serão investidos dos recursos públicos, porém é preciso lembrar que tal legislador deve escolher de forma coerente. Constata então um espaço para ação do legislador, mas acaba por reconhecer ao Tribunal Constitucional Federal alemão a possibilidade de avaliar se a escolha foi feita de modo mais eficaz para proteção da vida humana. Para identificação desse meio mais

45 BverfGE, 33, 303 (333). "Numerus clausus é a denominação de uma política adotada na Alemanha, em 1960, para limitar numericamente os ingressos de estudantes em determinados cursos universitários face à grande quantidade de interessados em áreas como direito, medicina, farmácia e outras. Estudantes que não lograram ser admitidos nas escolas de medicina das Universidades de Hamburgo e Munique contestaram a limitação com base no art. 12 da Lei Fundamental, que prevê o direito de todo alemão à livre escolha de sua profissão, seu posto de trabalho e seu centro de formação" (LEVIAS, Paulo Gilberto Cogo. Teoria dos direitos fundamentais sociais, p. 98). 
eficaz, propõem a aplicação do instrumental da proporcionalidade como critério de avaliação. ${ }^{47}$

O Supremo Tribunal Federal, com base na exposição de Alexy, tem tomado decisões de caráter pragmáticos no que se refere às normas sociais, ou seja, não tem autorizado o Poder Público de forma irresponsável a "reserva do financeiramente possível", prejudicando, algumas vezes, a coletividade.

Tal premissa fica clara no julgamento da ADPF 45 pelo nosso Tribunal Constitucional, onde retirou o papel dos Poderes Executivo e Legislativo de criar políticas públicas que pudessem atender a população de forma satisfatória. $\mathrm{O}$ Ministro Celso de Mello, como relator do imbróglio, entendeu pela possibilidade de controle judicial das políticas públicas, como medida de efetividade dos direitos sociais, em razão da omissão dos demais poderes constitucionais.

Ementa: Arguição de descumprimento de preceito fundamental. A questão da legitimidade constitucional do controle e da intervenção do Poder Judiciário em tema de implementação de políticas públicas, quando configurada hipótese de abusividade governamental. Dimensão política da jurisdição constitucional atribuída ao Supremo Tribunal Federal. Inoponibilidade do arbítrio estatal à efetivação dos direitos sociais, econômicos e culturais. Caráter relativo da liberdade de conformação do legislador. Considerações em torno da cláusula da "reserva do possível". Necessidade de preservação, em favor dos indivíduos, da integridade e da intangibilidade do núcleo consubstanciador do "mínimo existencial". Viabilidade instrumental da arguição de descumprimento no processo de concretização das liberdades positivas (direitos constitucionais de segunda geração).

Embora a decisão final tenha sido no sentido de considerar prejudicado o pedido - diante da implementação da política por lei posterior -, o teor da decisão merece referência, diante de sua defesa da possibilidade de o Poder Judiciário controlar políticas públicas mesmo diante da alegação da "reserva do possível", usando da fundamentação do mínimo existencial. Nas palavras de Celso de Mello:

Não obstante a formulação e a execução de políticas públicas dependam de opções políticas a cargo daqueles que, por delegação popular, receberam investidura em mandato eletivo, cumpre reconhecer que não se revela absoluta, nesse domínio, a liberdade de conformação do legislador, nem a de atuação do Poder Executivo. É que, se tais Poderes do Estado agirem de modo irrazoável ou procederem com a clara intenção de neutralizar, comprometendo-a, a eficácia dos direitos sociais, econômicos e culturais, afetando, como decorrência causal de uma injustificável inércia estatal ou de um abusivo comportamento governamental, aquele núcleo intangível consubstanciador de um conjunto irredutível de condições mínimas necessárias a uma existência digna e essenciais à própria sobrevivência do indivíduo, aí, então, justificar-se-á, como precedentemente já enfatizado - e até mesmo por razões fundadas em um imperativo ético-jurídico -, a possibilidade de intervenção do Poder Judiciário, em ordem a viabilizar, a 
todos, o acesso aos bens cuja fruição Ihes haja sido injustamente recusada pelo Estado.

Mascarar a destinação e alocação de recursos orçamentários por detrás do "mínimo existencial" ou da "reserva do possível" é, no dizer de Álvaro Ricardo de Souza Cruz,

a inexistência de qualquer programa político, a curto, médio e longo prazo, voltado para as ações sociais. O Direito moderno está sim sujeito aos argumentos de cunho econômico - de uma escassez de bens - mas também não poder virar as costas para os argumentos morais - como aqueles trazido por Rawls, no sentido de iguais direitos de liberdade, que parece servir para sustentar uma nova visão do que quer seja o mínimo existencial ${ }^{48}$. Assim, como é possível sustentar tal solução? ${ }^{49}$

Desta forma, utilizar a "reserva do possível" como uma "armadura" por parte do Estado para o não cumprimento de suas obrigações legais e constitucionais somente deverá ser considerada quando inviável e inadequada a comprovação de realmente não haver a disponibilidade de recursos financeiros existentes para tornar com caráter de efetividade social a prestação positiva reclamada junto ao Poder Público.

Por fim, ressalta Clèmerson Merlin Clève ${ }^{50}$ : "Incumbe ao Poder Público consignar na peça orçamentária as dotações necessárias para a realização progressiva dos direitos. Não se trata de adiar sua efetividade. Trata-se de estabelecer de modo continuado as ações voltadas para sua realização num horizonte de tempo factível".

\section{CONSIDERAÇÕES FINAIS}

Diante do que foi apresentado, pode-se verificar que há tempos o contexto mundial tem buscado alternativas para garantir condições viáveis de desenvolvimento que consiga proteger gerações (presente/futura), com o propósito primordial de não repetir as atrocidades sentidas com a II Guerra Mundial sobre os povos do planeta.

Para tanto, desde a Carta de São Francisco, a Declaração dos Direitos Humanos, a Carta de Bogotá, as Conferências de Estocolmo, a de Cairo, a ECO

48 “[...] podemos vislumbrar como mínimo existencial já dentro da argumentação moral, eis que aqui prevalece a perspectiva de reciprocidade de modo a se garantir a todos as condições materiais para que possam participar dos discursos de formação da vontade política na sociedade. Aqui os influxos da economia são afastados, pois sem os mesmos não há bases fundamentais para o funcionamento da democracia. Nesse instante a lógica da melhor alocação de recursos desaparece, eis que toda sociedade dispõe de um mínimo de recursos que viabilize a existência física/orgância das pessoas." (SOUZA CRUZ, Álvaro Ricardo de. Hermenêutica jurídica e(m) debate, p. 372)

49 Idem, p. 328.

50 CLÈVE, Clèmerson Merlin. A eficácia dos direitos fundamentais sociais. Revista de Direito Constitucional e Internacional, São Paulo: RT, 54/36-37, a. 14, jan./mar. 2006. 
92 e Rio +10, as nações vêm cristalizando o direito ao desenvolvimento no âmbito conceitual dos direitos humanos, principalmente quanto ao aspecto da sustentabilidade.

O direito ao desenvolvimento vem sendo tratado nestes encontros internacionais como direitos humanos sustentado na cooperação internacional, pautando-se nas dimensões de caráter fundamental, na solidariedade, na moral, na interdependência econômica e na manutenção da paz e da segurança mundial.

Vislumbra-se com as Conferências a possibilidade de desenvolver estratégias viáveis, com programas capazes de auxiliar a promoção do desenvolvimento, de modo a evitar o esgotamento dos recursos naturais do planeta e conflitos internos e externos, já que as diferenças econômicas, sociais e culturais são demasiadamente grandes entre os povos do mundo e criam ambientes tênues de grandes tensões e discórdias que afetam toda a humanidade.

Nessa realidade tênue, o desenvolvimento se apoia e deve observância aos novos paradigmas e valores no contexto de economia concebida pelo livre mercado, que deve para tanto integrar-se essa condição as dimensões social, ambiental e institucional, garantindo, assim, o tão almejado desenvolvimento sustentável para a qualidade de vida das presentes e futuras gerações.

Ignorar a questão do crescimento populacional, devastação ambiental, produção alimentícia e produção energética sob a alegação de que essa era a realidade do Protocolo de Brundtland é uma postura um tanto quanto "suicida", pois tais questões estão invadindo nossas casas sem ao menos bater à porta.

Assim, é uma postura bem racional a defesa de um novo paradigma que se sustente na afirmação de que proteger o meio ambiente é o mesmo que proteger os direitos fundamentais. E que todas as esferas do Poder Público, assim como os cidadãos, são titulares proativos de um dever, de um defender e de um preservar o meio ambiente.

Tal situação é tão presente nos dias de hoje que nossos Tribunais têm decidido em seus julgados que a cooperação (terceira dimensão) é primordial quando se verifica a colisão de direitos sobre o meio ambiente e demais direitos defendidos como fundamentais.

O Judiciário brasileiro tem buscado sopesar, em duas decisões do desenvolvimento, a sustentabilidade à noção de direitos humanos e fundamentais.

Dessa maneira, é de suma importância procedermos a uma análise pontual dos progressos e retrocessos dessas Conferências, já que o momento para refletir sobre essas questões é agora, pois a Rio +20 está muito próxima e, se bem articulada, será terra fértil para bons frutos. 


\section{REFERÊNCIAS}

ACCIOLY, Hildebrando. Manual de direito internacional público. 12. ed. São Paulo: Saraiva, 1996.

ALLEN, P. (Ed.). Food for the Future: conditions and contradictions of sustainability. New York: Paperback, 1993.

ALEXY, Robert. Teoria de los derechos fundamentales, Madrid: Centro de Estudos Políticos y Constitucional, 2002. p. 422 e 448.

ANDERSON, Perry. Balanço do neoliberalismo. In: SADER, Emir; GENTILI, Pablo (Org.). Pós-neoliberalismo. As políticas sociais e o Estado Democrático. Rio de Janeiro: Paz e Terra, 1998.

ANTUNES, Paulo de Bessa. Direito ambiental. 13. ed. rev. e atual. Rio de Janeiro: Lumen Juris, 2011.

BEHRING, Elaine; BOSCHETTI, Ivanete. Política social: fundamentos e história. São Paulo: Cortez, 2006.

BENJAMIN, Antônio Herman V. Introdução ao direito ambiental brasileiro. Revista de Direito Ambiental, São Paulo: RT, n. 14, abr./jun. 1999.

BOBBIO, Noberto. A era dos direitos. Rio de Janeiro: Campus, 1996.

BONAVIDES, Paulo (Coord.); RODRIGUES, Geisa de Assis et al. Comentários à Constituição Federal de 1988. Rio de Janeiro: Forense, 2009.

BRUM, Argemiro J. Desenvolvimento econômico brasileiro. 20. ed. Petrópolis: Vozes C/ Ed. Unijuí, 1999.

BUARQUE, Cristovam. A desordem do progresso. 4. ed. São Paulo: Paz e Terra, 1993.

BUCI-GLUCKSMANN, Christinne. Gramsci e o Estado. Rio de Janeiro: Paz e Terra, 1980.

BUCCI, Maria Paula Dallari. O conceito de políticas públicas em direito. In: BUCCI, Maria Paula Dallari (Org.). Políticas públicas: reflexões sobre o conceitos jurídico. São Paulo: Saraiva, 2006.

CALDAS, Ricardo Wahrendorff (Coord.). Políticas públicas: conceitos e práticas. Belo Horizonte: Sebrae/MG, 2008. Disponível em: <http://www.portaldodesenvolvimento. com.br/conceitos-basicos/81-politicas-publicas/123-conceitos-de-politicas-publicas>. Acesso em: 25 abr. 2012.

CAMPOS, Dejalma de. Direito financeiro e orçamentário. São Paulo: Atlas, 1995.

CAPRA, Fritjof. O ponto de mutação. 25. ed. São Paulo: Cultrix, 1999.

CLÈVE, Clèmerson Merlin. A eficácia dos direitos fundamentais sociais. Revista de Direito Constitucional e Internacional, São Paulo: RT, 54/36-37, a. 14, jan./mar. 2006.

CRUZ, Álvaro Ricardo de. Hermenêutica jurídica e(m) debate, p. 372.

DELGADO, Ana Paula Teixeira. O direito ao desenvolvimento na perspectiva da globalização: paradoxos e desafios. São Paulo: Renovar, 2001.

FALEIROS, Vicente. A política social do Estado capitalista. As funções da previdência e da assistência sociais. 5. ed. São Paulo: Cortez, 1987. 
FARIA, José Eduardo. O direito na economia globalizada. São Paulo: Malheiros, 1999.

GARCIA-AMADOR, F. V. El derecho internacional del desarrollo una nueva dimension del derecho internacional econômico. Madrid: Editorial Civitas S.A., 1987.

HAQ, Mahbub ul. O paradigma do desenvolvimento humano sustentável. Disponível em: www.undp.org.br. Acesso em: 31 mar. 2001.

HARGROVES, K.; SMITH, M. (Ed.). The natural advantage of nations: business opportunities, innovation and governance in the 21st Century. New York: Earthscan/James \& James, 2005.

IANNI, Octavio. A sociedade global. 5. ed. Rio de Janeiro: Civilização Brasileira, 1997. IHERING, Rudolf Von. A luta pelo direito. 16. ed. Rio de Janeiro: Forense, 1997.

ISA, Felipe Gomez. Cuadernos Deusto de derechos humanos: Ios derechos humanos al desarrollo: entre la justicia y la solidaridad. Bilbao: Universidade Deusto, 1998.

LAFER, Celso. A reconstrução dos direitos humanos: um diálogo com o pensamento de Hannah Arendt. São Paulo: Cia. das Letras, 1988.

MARCIAL, Danielle; ROBERT, Cínthia; SÉGUIN, Elida. O direito do desenvolvimento. Rio de Janeiro: Lumem Juris, 2000.

MATHIAS, G.; SALAMA, P. O Estado superdesenvolvido. São Paulo: Brasiliense, 1983.

MELLO, Celso D. de Albuquerque. Curso de direito internacional público. 11. ed. Rio de Janeiro: Renovar, v. 1 e 2, 1997.

MOISÉS, Cláudia Perrone. Direito ao desenvolvimento e investimentos estrangeiros. São Paulo: Oliveira Mendes, 1998.

. Direitos humanos e desenvolvimento: a contribuição das nações unidas. In: AMARAL JÚNIOR, Alberto do; MOISÉS, Cláudia Perrone (Org.). O cinquentenário da declaração universal dos direitos do homem. São Paulo: Edusp, 1999.

MORIN, Edgar. Introdução à política do homem - Argumentos políticos. São Paulo: Forense, 1965.

. Terra-pátria. 2. ed. Porto Alegre: Sulina, 1995.

NAVARRO, Vicente. Produção e Estado de bem-estar: o contexto das reformas. In: LAURELL, Asa Cristina (Org.). Estado e políticas sociais no neoliberalismo. São Paulo: Cortez, 1995.

POULANTZAS, N. Poder político e classes sociais. São Paulo: Martins Fontes, 1977.

RANGEL, Vicente Marotta. Direito e relações internacionais. 6. ed. São Paulo: Revista dos Tribunais, 2000.

SILVA, Geraldo Eulálio do Nascimento. Direito ambiental internacional: meio ambiente, desenvolvimento sustentável e os desafios da nova ordem mundial. Rio de Janeiro: Thex, 1995.

SOUZA, Washington Peluso Albino de. Primeiras linhas de direito econômico. 4. ed. São Paulo: LTD, 1999.

STACCONE, G. Gramsci: 100 anos - Revolução e política. São Paulo: Petrópolis, 1991. 
TRINDADE, Antônio Augusto Cançado. O legado da declaração universal e o futuro da proteção internacional dos direitos humanos. In: AMARAL JÚNIOR, Alberto do; MOISÉS, Cláudia Perrone (Org.). O cinquentenário da declaração universal dos direitos do homem. São Paulo: Edusp, 1999.

VIANA, Nildo. O capitalismo na era da acumulação integral. Rio de Janeiro: Ciência Moderna, 2007.

YOUNG, Lincoln; HAMSHIRE, Jonathon. Promoting Practical Sustainability.

Canberra (Australia): Australian Agency for International Development (AusAID), 2000 (and reprints). 